ADMA

Gurnal Pengabdian dan Pemberdayaan Masyarakat
Tahun, Vol.1, No.2, pp.19-26

Doi: $x x x x x x x x x$

\title{
Implementasi Teknik Metastasis Berbasis Keluarga untuk Mewujudkan Kampung Yanggandur Merauke sebagai Kampung Melek Aksara
}

\author{
Henie Poerwandar Asmaningrum, Gerzon Jokomen Maulany², Martha Betaubun², \\ Nasrawati ${ }^{4}$ \\ poerwandar@unmus.ac.id 1 , maulany@unmus.ac.id ${ }^{2}$, \\ marthabetaubun@unmus.ac.id ${ }^{3}$, nasrawati@unmus.ac.id ${ }^{4}$
}

1,2,3,4Universitas Musamus

\begin{abstract}
Article History:
Received: 15-04-2021

Revised: 16-06-2021

Accepted: 17-07-2021
\end{abstract}

\begin{abstract}
The goal of this community service program is to make Yanggandur Village a Literary Literacy Village. The target of this program is 20 families who are still illiterate in Yanggandur Village. The method of implementing the program is a family-based metastasis strategy. Technically, this program is integrated with the Musamus University Community Service Program. 12 students act as the first tutor who will train the executive tutor who is one of the target family members. Furthermore, the executive tutor will teach other family members. At the end of the program, $36 \%$ of participants were able to write word for word in one or two sentences fluently and correctly, $56 \%$ of participants had been able to read word for word in one or two sentences correctly, and $60 \%$ of participants had been able to add and subtract shapes dozens. In conclusion, the implementation of family-based metastasis techniques can improve the ability to write, read, and count in the people of Yanggandur Village Merauke.
\end{abstract}

Keywords: Metastasis, keluarga, melek, aksara,

\section{Pendahuluan}

Sebagai salah satu aspek penting dalam pembangunan nasional suatu negara, pendidikan saat ini dituntut agar mampu berperan secara aktif dalam mencetak sumber daya manusia. Semakin tinggi tingkat kecerdasan makin tinggi pula kualitas sumber daya manusia. Pendidikan dinyatakan berhasil apabila mampu menhasilkan manusia yang berkualitas secara spiritual, intelegensia, maupun keahlian. Hal ini sangat mempengaruhi tercapinya tujuan pembangunan nasional dari suatu negara.

Namun hingga saat ini masih banyak masyarakat di Indonesia, khusunya yang berada di bawah garis kemiskinan yang masih menderita buta aksara atau buta huruf. Bahkan menurut data Kementrian Pendidikan dan Kebudayaan (Kemendikbud), jumlah buta aksara di Indonesia hingga akhir 2014 mencapai 5,97\% juta jiwa. Jumlah tersebut merupakan $3.7 \%$ dari total penduduk yang ada di Indonesia (Pers, 2019).

Program Pemberantasan Buta Aksara, sebetulnya sudah berjalan sejak jaman kemerdekaan, namun dalam perjalanannya terjadi pasang surut, bahkan dalam sejarahnya 
ADMA

Gurnal Pengabdian dan Pemberdayaan Masyarakat
Tahun, Vol.1, No.2, pp.19-26

Doi: $x x x x x x x x x$

negara Indonesia pernah memproklamirkan bebas 3 buta. Tetapi karena tidak dipergunakan ketrampilan menyebabkan banyak yang menjadi buta kembali (Hiryanto, 2008).

Kampung Yanggandur adalah salah satu kampung lokal yang terletak di dalam areal Taman Nasional Wasur. Penduduk Kampung Yanggandur hingga saat ini masih homogen, belum banyak penduduk dari luar yang menetap di kampung Yanggandur sehingga belum banyak terjadi pembauran. Meskipun sebagian besar adalah penduduk asli kampung Yanggandur tetapi ada juga penduduk pendatang yang berasal dari suku suku Key, Muyu, NTT, dan Jawa. Mata pencaharian hidup penduduk Kampung Yanggandur hingga saat ini belum banyak berubah yaitu berburu, meramu dan menangkap ikan. Ketergantungan penduduk kampung terhadap alam masih sangat tinggi. Kegiatan bercocok tanam hanya dilakukan secara tradisional yaitu untuk menanam kumbili, pisang, keladi dan ubi. Hasil bercocok tanam lebih banyak digunakan untuk memenuhi kebutuhan makan keluarga (Resubun, 2009).

Permasalahan umum di Kampung Yanggandur antara lain kurang aktifnya tenaga medis dan tenaga pendidik. Pelayanan kesehatan dan pendidikan di Kampung Yanggandur menjadi terbengkalai. Hal ini menyebabkan rendahnya tingkat kesehatan dan pendidikan di Kampung Yanggandur. Terutama pada masalah pendidikan, masih banyak masyarakat Kampung Yanggandur yang masih buta aksara. Pada usia belajar dan usia produktif, masyarakat kampung belum dapat membaca dan menghitung. Selain itu pada masa pandemi COVID 19 seperti sekarang ini, kegiatan belajar mengajar di sekolah dihentikan sejak bulan Maret 2020 hingga saat ini. Hal tersebut dilakukan dalam rangka prioritas kesehatan masyarakat, terutama peserta didik, dari ancaman virus COVID 19. Kondisi ini membuat peserta didik tidak dapat melanjutkan proses pembelajaran membaca dan menulis.

Ketidakmampuan masyarakat dalam membaca dan menulis akan menjadikan masyarakat rentan terhadap tindak kriminal berupa penipuan atau lainnya yang dilakukan oleh oknum tidak bertanggungjawab. Hal tersebut juga menjadi kendala bagi masyarakat untuk meningkatkan taraf hidupnya. Dengan pendidikan dasar yang memadai, masyarakat akan mampu membangun kehidupan sosial dan ekonomi yang lebih baik.

Pelaksanaan program pengabdian masyarakat yang diintegrasikan dengan kegiatan KKN merupakan wujud peran Universitas Musamus dalam masyarakat. Sebagai akademisi, mahasiswa dituntut untuk memiliki peran dalam masyarakat. Peran tersebut antara lain mencari solusi untuk masalah-masalah yang dihadapi masyarakat baik masalah sosial, ekonomi, maupun pembangunan. Salah satu wadah untuk melatih mahasiswa mempersiapkan diri di masyarakat adalah KKN (Kuliah Kerja Nyata). KKN dengan melibatkan mahasiswa diharapkan mampu meningkatkan empati dan kepedulian mahasiswa, 


\section{ADMA}

Gurnal Pengabdian dan Pemberdayaan Masyarakat
Tahun, Vol.1, No.2, pp.19-26

Doi: $x x x x x x x x x$

melaksanakan terapan IPTEKS secara bersama-sama dan interdispliner dalam memecahkan masalah yang terjadi di Kampung Yanggandur.

\section{Metode}

Pelaksanaan pengabdian masyarakat mengikuti alur yang ditunjukkan pada gambar 1 .

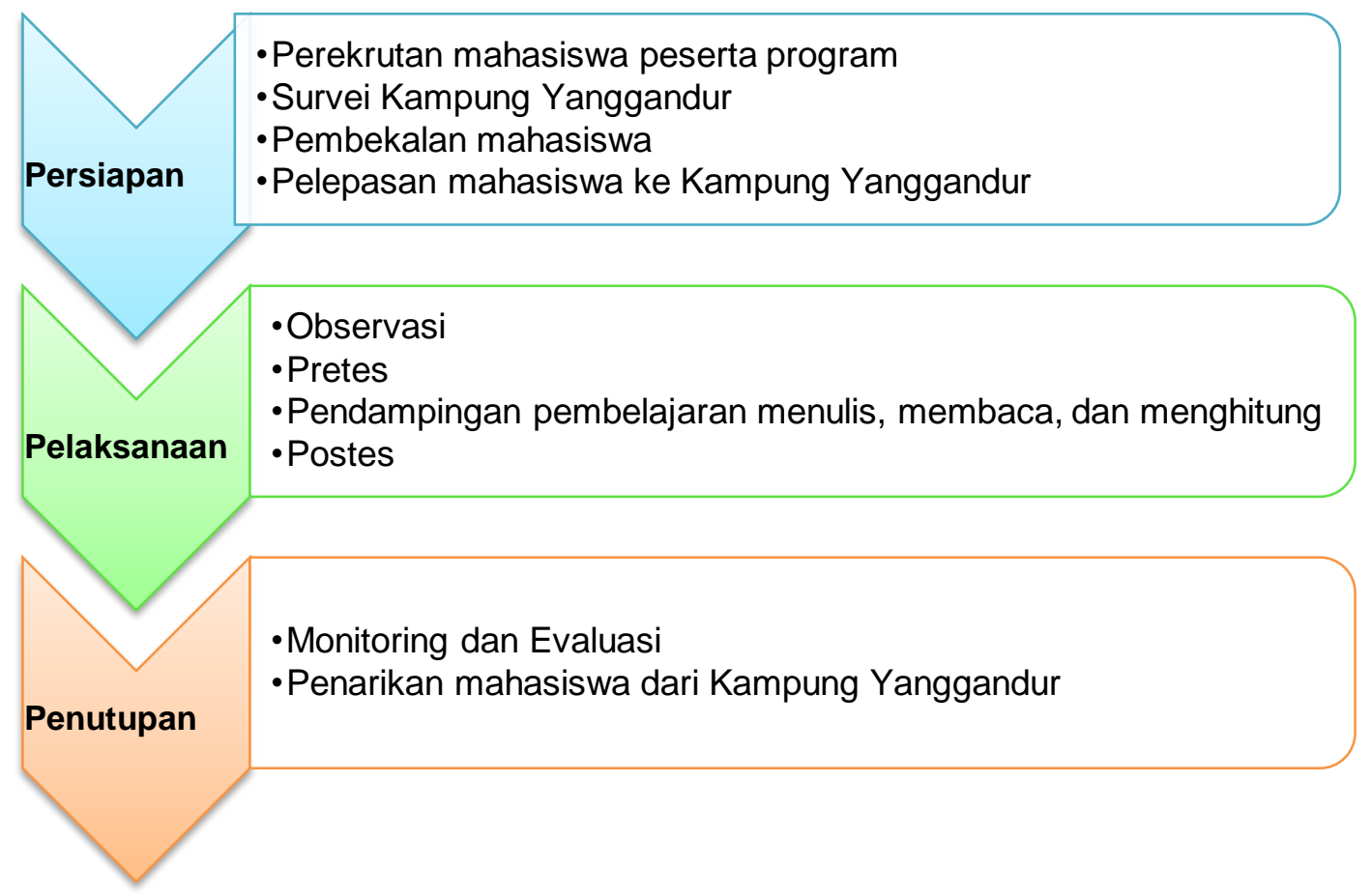

Gambar 1. Alur pelaksanaan program pengabdian masyarakat

Sasaran kegiatan pengabdian adalah 20 keluarga yang berada pada kampung Yanggandur. Tutor ahli merupakan mahasiswa Universitas Musamus yang terlibat dalam kegiatan KKN. Tutor ahli masing-masing bertanggungjawab terhadap perkembangan pendidikan keaksaraan 2 keluarga. Tutor pelaksana merupakan anggota keluarga dari keluarga sasaran kegiatan pengabdian. Anggota keluarga yang akan diajarkan diprioritaskan yang berusia 6 - 13 tahun. Pelaksanaan program pengentasan buta aksara dilaksanakan secara bertahap yaitu keaksaraan dasar selama 114 jam, keaksaraan lanjutaan selama 66 jam, dan keaksaraan mandiri selama 36 jam.

Langkah-langkah teknis pelaksanaan strategi metastesis berbasis keluarga adalah sebagai berikut (Mariyono, 2016).

1) Pengumpulan data

Dalam pelaksanaannya program pengentasan buta aksara diawali dengan pendataan keluarga di kampung Yanggandur. Keluarga tersebut didata jumlah anggota keluarga dan 


\section{ADMA}

Gurnal Pengabdian dan Pemberdayaan Masyarakat
Tahun, Vol.1, No.2, pp.19-26

Doi: $x x x x x x x x x$

jumlah anggota keluarga yang telah bebas buta aksara. Anggota keluarga yang bebas buta aksara akan dijadikan tutor pelaksana dalam kelompok keluarganya. Jika semakin banyak anggota keluarga yang telah melek aksara maka akan semakin baik proses pelaksanaan program ini.

2) Pelatihan tutor ahli dan tutor pelaksana

Setelah data diperoleh, diperlukan tutor pertama yang telah dilatih tentang metode pembelajaran. Tutor pertama adalah mahasiswa yang akan melatih calon tenaga tutor pelaksana di keluarga. Tutor pelaksana dipercayakan kepada salah seorang anggota keluarga yang telah mahir calistung dan telah dilatih oleh tutor pertama.

3) Bahan dan metode pembelajaran

Setelah itu dipersiapkan bahan dan metode pembelajaran yang sesuai dengan peserta. Bahan dan metode pembelajaran direncanakan berbasis keluarga, kearifan lokal, dan kondisi terkini masyarakat. Huruf atau kata dan suku kata disesuaikan dengan kebutuhan dan lingkungan.

4) Monitoring dan evaluasi

Dalam pelaksanaannya program selalu dimonitoring dan dievaluasi oleh tutor ahli dan penanggungjawab. Proses monitoring dilakukan secara mendalam dan berkala. Hasil belajar dikonversi melalui rubrik penilaian yang ditampilkan pada tabel 1.

Tabel 1. Rubrik penilaian tes

\begin{tabular}{lllll}
\hline No & \multicolumn{1}{c}{ Menulis } & \multicolumn{1}{c}{ Membaca } & \multicolumn{1}{c}{ Berhitung } & Skor \\
\hline $\mathbf{1}$ & $\begin{array}{l}\text { Tidak dapat menulis } \\
\text { huruf }\end{array}$ & $\begin{array}{l}\text { Tidak dapat } \\
\text { membaca/diam }\end{array}$ & $\begin{array}{l}\text { Tidak mengenal } \\
\text { angka }\end{array}$ & 0 \\
\hline $\mathbf{2}$ & $\begin{array}{l}\text { Dapat menulis huruf } \\
\text { dengan lancar dan } \\
\text { benar }\end{array}$ & $\begin{array}{l}\text { Mengenal dan } \\
\text { menyebutkan huruf A-Z } \\
\text { dengan benar }\end{array}$ & $\begin{array}{l}\text { Sudah mengenal } \\
\text { angka dari 1-100 }\end{array}$ & 1 \\
\hline $\mathbf{3}$ & $\begin{array}{l}\text { Dapat menulis kata } \\
\text { dalam satu atau dua } \\
\text { kalimat dengan tidak } \\
\text { lancar tetapi benar }\end{array}$ & $\begin{array}{l}\text { Membaca kata demi } \\
\text { kata dalam satu kalimat } \\
\text { dengan tidak lancar }\end{array}$ & $\begin{array}{l}\text { Dapat menjumlahkan } \\
\text { dan mengurangkan } \\
\text { bentuk satuan }\end{array}$ & 2 \\
\hline $\begin{array}{l}\text { Dapat menulis kata } \\
\text { demi kata dalam satu } \\
\text { atau dua kalimat } \\
\text { dengan lancar dan } \\
\text { benar }\end{array}$ & $\begin{array}{l}\text { Membaca kata demi } \\
\text { kata dalam satu atau } \\
\text { dua kalimat dengan } \\
\text { benar }\end{array}$ & $\begin{array}{l}\text { Dapat menjumlahkan } \\
\text { dan mengurangkan } \\
\text { bentuk puluhan }\end{array}$ & 3 \\
\hline $\begin{array}{l}\text { Dapat menulis kata } \\
\text { demi kata dalam tiga } \\
\text { kalimat dengan lancar } \\
\text { dan benar }\end{array}$ & $\begin{array}{l}\text { Membaca kata demi } \\
\text { kata dalam kalimat } \\
\text { dengan lancar dan } \\
\text { benar }\end{array}$ & $\begin{array}{l}\text { Dapat menjumlahkan } \\
\text { atau mengurangkan, } \\
\text { dalam bentuk ratusan }\end{array}$ & 4 \\
\hline
\end{tabular}


ADMA

Dennal Pengabdian dan Pemberdayaan Masyarakat
Tahun, Vol.1, No.2, pp.19-26

Doi: $x x x x x x x x x$

\section{Pembahasan}

Pada tanggal 5 Oktober 2020, dilakukan perekrutan mahasiswa peserta pengabdian masyarakat di Jurusan Pendidikan Kimia. Mahasiswa tersebut adalah mahasiswa Jurusan Pendidikan Kimia, angkatan 2017. Setelah kegiatan perekrutan selesai, mahasiswa dibagi menjadi kelompok-kelompok kecil kemudian diarahkan pada tutor ahli. Tutor ahli adalah dosen-dosen di Universitas Musamus yang bertugas untuk mendampingi mahasiswa dalam pembuatan media pembelajaran dan cara penerapannya.

Pada tanggal 15 - 16 Oktober 2020 dilakukan kegiatan Pembekalan Program pengabdian masyarakat di Jurusan pendidikan Kimia. Kegiatan dibuka oleh Ketua LP2M, dan diisi oleh pemateri dari Wakil Dekan FKIP, Ketua Jurusan Pendidikan Kimia, Sekertaris LP2M, dan Dosen FKIP. Tujuan pelaksanaan pembekalan adalah memberikan informasi kepada mahasiswa tentang pelaksanaan Program pengabdian masyarakat, teknis pembuatan laporan, serta etika profesional yang harus dijaga saat berada di Kampung Yanggandur.

Pada tanggal 2 November 2020 dilakukan pelepasan mahasiswa peserta Program pengabdian masyarakat dari Universitas Musamus ke Kampung Yanggandur. Setelah melakukan observasi selama 3 hari, mahasiswa mulai menyusun strategi pembelajaran dengan menggunakan media-media pembelajaran yang telah disiapkan. Mahasiswa bertugas sebagai tutor pertama yang mengajarkan menulis, membaca, dan menghitung pada masyarakat, sebagai tutor pelaksana dalam keluarga. Proses pembelajaran menggunakan media ditunjukkan pada gambar 1 .
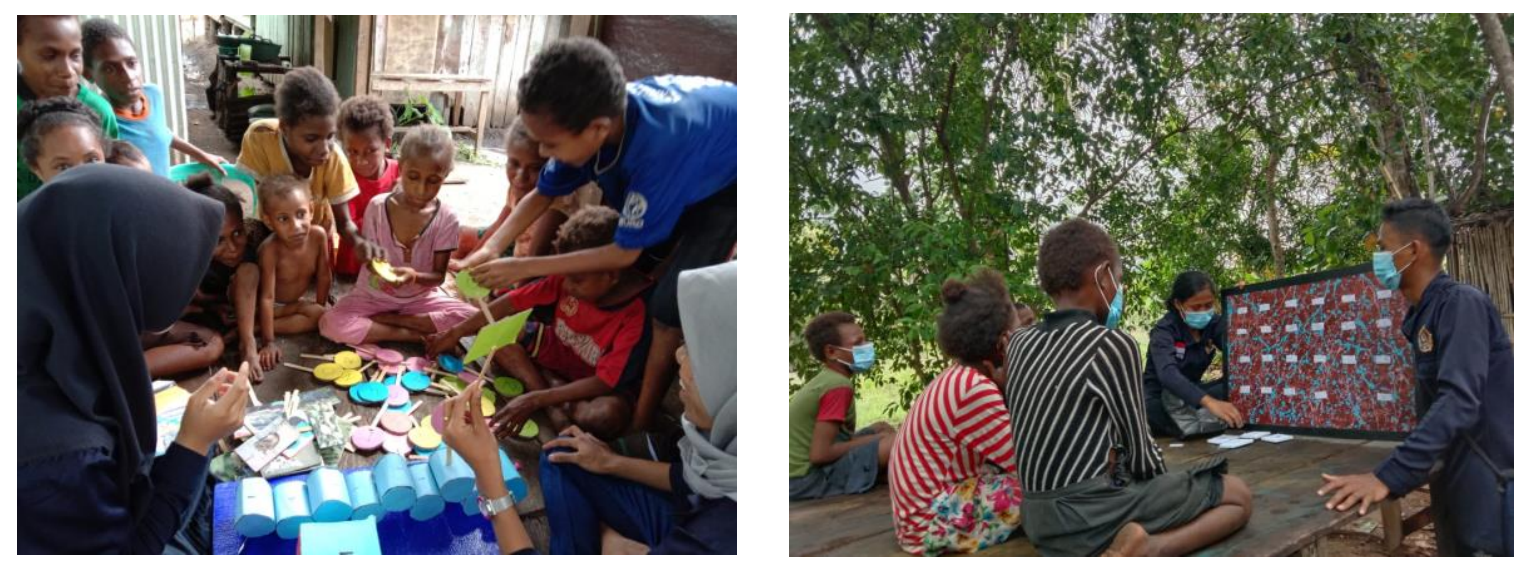

Gambar 1. Proses pembelajaran

Sebelum dilakukan proses pembelajaran, tutor pelaksana diberi pretes. setelah dilakukan proses pembelajaran selama kurang lebih 3 minggu, dilakukan postes untuk mengetahui peningkatan kemampuan tutor pelaksana. Hasil analisis peningkatan kemampuan tutor pelaksana ditunjukkan pada tabel 2.

Tabel 2. Persentase peningkatan pemahaman tutor pelaksana 
Pretes Postes

1 Menulis:
a. Peserta tidak dapat menulis huruf

$20 \% \quad 0 \%$
b. Peserta telah dapat menulis huruf dengan lancar dan benar
$48 \% \quad 20 \%$
c. Peserta telah dapat menulis kata dalam satu atau dua kalimat dengan tidak lancar tetapi benar
$32 \% \quad 44 \%$
d. Peserta telah dapat menulis kata demi kata dalam satu atau dua kalimat dengan lancar dan benar
e. Peserta telah dapat menulis kata demi kata dalam tiga kalimat dengan lancar dan benar
$0 \% \quad 36 \%$

$0 \% \quad 0 \%$

2 Membaca:
a. Peserta tidak dapat membaca/diam
$8 \% \quad 0 \%$
b. Peserta telah dapat mengenal dan menyebutkan huruf $A-Z$ dengan benar
c. Peserta telah dapat membaca kata demi kata dalam satu kalimat dengan tidak lancar
d. Peserta telah dapat membaca kata demi kata dalam satu atau dua kalimat dengan benar
e. Peserta telah dapat membaca kata demi kata dalam kalimat $\quad 0 \% \quad 0 \%$ dengan lancar dan benar

3 Menghitung:
a. Peserta tidak mengenal angka
b. Peserta telah dapat mengenal angka dari 1-100

$\begin{array}{cc}16 \% & 0 \% \\ 28 \% & 16 \% \\ 56 \% & 24 \%\end{array}$
c. Peserta telah dapat menjumlahkan dan mengurangkan bentuk satuan
d. Peserta telah dapat menjumlahkan dan mengurangkan bentuk puluhan
e. Peserta telah dapat menjumlahkan atau mengurangkan, $0 \% \quad 0 \%$ dalam bentuk ratusan

Tabel 2 menunjukkan bahwa terjadi peningkatan kemampuan menulis. Semula sebanyak $20 \%$ peserta tidak mampu menulis, setelah didampingi melalui program pengabdian masyarakat, terdapat $0 \%$ peserta yang tidak mampu menulis. Artinya semua peserta sudah dapat menulis diakhir program. Semula sebanyak $48 \%$ peserta hanya mampu menulis huruf dengan lancar dan benar, pada akhir program tersisa sebanyak $20 \%$ peserta yang hanya mampu menulis huruf dengan lancar dan benar. Semula terdapat $32 \%$ peserta yang dapat menulis kata dalam satu atau dua kalimat dengan tidak lancar tetapi benar, kemudian pada akhir program terdapat $44 \%$ peserta yang dapat menulis kata dalam satu atau dua kalimat dengan tidak lancar tetapi benar. Semula terdapat $0 \%$ peserta yang dapat menulis kata demi kata dalam satu atau dua kalimat dengan lancar dan benar, artinya tidak ada peserta yang dapat menulis kata demi kata dalam satu atau dua kalimat dengan lancar dan benar. Namun pada akhir program terdapat $36 \%$ peserta yang dapat menulis kata demi kata dalam satu atau dua kalimat dengan lancar dan benar. 


\section{ADMA}

Gurnal Pengabdian dan Pemberdayaan Masyarakat
Tahun, Vol.1, No.2, pp.19-26

Doi: $x x x x x x x x x$

Tabel 2 menunjukkan bahwa terjadi peningkatan kemampuan membaca. Semula sebanyak $8 \%$ peserta tidak dapat membaca/diam, setelah didampingi melalui program pengabdian masyarakat, terdapat $0 \%$ peserta yang tidak dapat membaca/diam. Artinya semua peserta sudah dapat membaca diakhir program. Semula sebanyak $40 \%$ peserta hanya mampu mengenal dan menyebutkan huruf $A-Z$ dengan benar, pada akhir program tersisa sebanyak $8 \%$ peserta yang hanya mampu mengenal dan menyebutkan huruf $A-Z$ dengan benar. Semula terdapat $52 \%$ peserta yang dapat membaca kata demi kata dalam satu kalimat dengan tidak lancar, kemudian pada akhir program terdapat 36\% peserta yang dapat membaca kata demi kata dalam satu kalimat dengan tidak lancar. Semula terdapat $0 \%$ peserta yang dapat membaca kata demi kata dalam satu atau dua kalimat dengan benar, artinya tidak ada peserta yang dapat membaca kata demi kata dalam satu atau dua kalimat dengan benar. Namun pada akhir program terdapat $56 \%$ peserta yang dapat membaca kata demi kata dalam satu atau dua kalimat dengan benar.

Tabel 2 juga menunjukkan bahwa terjadi peningkatan kemampuan menghitung. Semula sebanyak $16 \%$ peserta tidak mengenal angka, setelah didampingi melalui program pengabdian masyarakat, terdapat $0 \%$ peserta yang tidak mengenal angka. Artinya semua peserta sudah dapat mengenal angka. Semula sebanyak $28 \%$ peserta hanya mampu mengenal angka dari 1-100, pada akhir program tersisa sebanyak $16 \%$ peserta yang hanya mampu mengenal angka dari 1-100. Semula terdapat $56 \%$ peserta yang dapat menjumlahkan dan mengurangkan bentuk satuan, kemudian pada akhir program terdapat $24 \%$ peserta yang dapat menjumlahkan dan mengurangkan bentuk satuan. Semula terdapat $0 \%$ peserta yang dapat menjumlahkan dan mengurangkan bentuk puluhan, artinya tidak ada peserta yang dapat menjumlahkan dan mengurangkan bentuk puluhan. Namun pada akhir program terdapat $60 \%$ peserta yang dapat menjumlahkan dan mengurangkan bentuk puluhan.

Hasil ini sejalan dengan hasil penelitian Ansori (2012) yaitu (1) Proses pembelajaran pendidikan keaksaraan berbasis keluarga adalah pendamping keluarga mempunyai peranan penting, karena sebagian besar pembelajaran dilakukan bersama pendamping keluarga, tutor hanya sebagai pemantau, mengevaluasi hasil belajar di rumah (2) Hasil dari pembelajaran tersebut warga belajar mampu membaca, menulis, dan berhitung (3) Dampak yang diperoleh oleh warga belajar adalah warga belajar mempu meningkatkan pendapatannya setelah mengikuti pendidikan keaksaraan berbasis keluarga.

Pelaksanaan program pengabdian kepada masyarakat yang diintegrasikan dengan KKN sangat membantu masyarakat di pedesaan, salah satu contohnya adalah program pemberdayaan dan pemberantasan buta aksara. Pengalaman yang didapatkan oleh mahasiswa sebagai peserta KKN juga sangat bermakna dalam kehidupan perkuliahannya. Dimana mahasiswa diharapkan dapat lebih memahami dan mengerti kebutuhan masyarakat 


\section{ADMA}

Gurnal Pengabdian dan Pemberdayaan Masyarakat
Tahun, Vol.1, No.2, pp.19-26

Doi: $x x x x x x x x x$

secara kompleks serta bagaimana cara beradaptasi dan berinteraksi dengan masyarakat dan lingkungan yang baru (Patahuddin, Syawal, \& Arham, 2017). Pada tanggal 2 Desember 2020

dilakukan penarikan mahasiswa program pengabdian masyarakat dari Kampung Yanggandur.

\section{Kesimpulan}

Pada akhir program terdapat 36\% peserta telah dapat menulis kata demi kata dalam satu atau dua kalimat dengan lancar dan benar, $56 \%$ peserta telah dapat membaca kata demi kata dalam satu atau dua kalimat dengan benar, dan $60 \%$ peserta telah dapat menjumlahkan dan mengurangkan bentuk puluhan. Kesimpulannya implementasi teknik metastasis berbasis keluarga dapat meningkatkan kemampuan menulis, membaca, dan menghitung pada masyarakat Kampung Yanggandur Merauke.

\section{Ucapan Terimakasih}

Ucapan terimakasih diberikan kepada Rektor Universitas Musamus dan Ketua LPPM Universitas Musamus yang telah memberikan kesempatan dan mendanai peneitian ini melalui Hibah Pengabdian Kepada Masyarakat Skim Pendampingan Desa Mitra DIPA UNMUS 2020. Ucapan terimakasih juga disampaikan kepada Pimpinan FKIP Universitas Musamus, rekanrekan dosen dan mahasiswa yang telah bekerjasama dalam kegiatan pengabdian kepada masyarakat.

\section{Daftar Pustaka}

Ansori, A.-B. (2012). Proses Pembelajaran Pendidikan Keaksaraan Berbasis Keluarga di Pusat Kegiatan Belajar Masyarakat Kandaga Desa Mayang Kecamatan Cisalak Kabupaten Subang. Jurnal IImiah Program Studi Pendidikan Luar Sekolah STKIP Siliwangi Bandung, 1(1).

Hiryanto. (2008). Kebijakan Program Pemberantasan Buta Aksara. Yogyakarta.

Mariyono. (2016). Strategi Pemberantasan Buta Aksara Melalui Penggunaan Teknik Metastasis Berbasis Keluarga. Pancaran, 5(1), 55-66.

Patahuddin, Syawal, \& Arham. (2017). Inovasi Keaksaraan Untuk Pemberdayaan dan Pemberantasan Buta Aksara di Kabupaten Enrekang. Jurnal Dedikasi Masyarakat, 1(1).

Pers, P. S. (2019). Jumlah Penduduk Buta Aksara Turun Menjadi 3,29 Juta. Retrieved from https://www.kemdikbud.go.id/main/blog/2019/08/jumlah-penduduk-buta-aksara-turun-menjadi329-juta

Resubun, T. (2009). Hasil Base Line Survey Sosial, Ekonomi Dan Budaya (Dengan Pendekatan Target Millenium Development Goals) di Kampung Yanggandur Distrik Sota, Kabupaten Merauke. Retrieved from https://docplayer.info/36947181-Laporan-mdgs-kampungyanggandur.html 